\title{
Need Analysis to Develop Adaptive Contextual Learning Model of Integrated Science by Integrating Digital Age Literacy for Grade VIII Students
}

\author{
Asrizal $^{1)}$, Ali Amran ${ }^{2)}$, Azwar Ananda ${ }^{3)}$, Festiyed ${ }^{1)}$ \\ 1) Physics Departement, FMIPA Universitas Negeri Padang \\ 2) Chemistry Departement, FMIPA Universitas Negeri Padang \\ 3) Social Science Education, FIS Universitas Negeri Padang asrizal@fmipa.unp.ac.id
}

\begin{abstract}
Good competence of students is very important in the 21 st century. Integrated curriculum is a good way to develop student's competence in this century. For this reason, integrated science learning and integration of literacy in learning are important for students. However, integrated science and literacy can't be implemented well. Solution of this problem is to develop adaptive contextual learning model of integrated science by integrating digital age literacy. Objective of the initial research is to describe the potency which supports the implementation of integrated science learning, the implementation of science learning in school, the characteristics of students, and the digital age literacy. Type of research is descriptive research. As research subjects were science teachers and students who study science in three junior high schools in Padang. Instruments to collects the data were observation sheet, questionnaire sheet, and literacy test sheet. Data were analyzed by using descriptive statistics analysis. The results of the preliminary research are: 1). average value of supporting factors of the implementation of integrated science is 76.83 which classified into good category, 2). average value of contextual learning and integrated learning materials of science in learning respectively 48.3 and 37.5 and these values can be entered into low category, 3). characteristics of students in background, interest, attitudes, learning motivation, and learning style are entered into good category with average value of 65.9, and 4). average value of digital age literacy of students is 42,92 which grouped into low category.
\end{abstract}

Keywords. Need Analysis, Contextual learning, Integrated Science, Digital age literacy

\section{Introduction}

Integrated curriculum is a good way to develop student's competence in the 21 st century. Integration in various fields of science will help students to understand natural phenomenon, problem solving, and develop their competences. There are some generic competencies which can be developed with integrated curriculum such as cooperation, creativity, communication, literacy skills, and critical thinking. An important thing in integrated curriculum is many students are involved in school as they are learning in an interdisciplinary environment (Drake, 2016).

In 2013 curriculum learning content in junior high school is based on integrated concepts from various disciplines of science. In essence, natural science is developed as subject in integrated science. Concept of integration is shown in core competence and basic competence. In one basic competence has integrated of science concepts from the field of biology, physics, chemistry, and earth sciences and space.

The government also encourages the improvement of student competences through school literacy movement. Literacy can help students in performing their 
functions in learning and daily life. Literacy is very important skill area in learning because it affects skills to acquire other academic fields (Carroll, 2013).

Integrated science learning and integration of literacy in learning can't be implemented well. First reality is integrated science textbook tend to refer to one field of science such as physics, chemistry, or biology (Yulianti, 2013). Second reality is science teachers DIY province have some problems in applying integrated science learning (Maryati, 2012). Third reality is literacy score of Indonesian students is low (Gurria, 2010, 2014).

The real condition both integrated science and integration of literacy in learning isn't suitable with ideal condition. This gap indicates problem from this research. Alternative solution of this problem is to develop adaptive contextual learning model of integrated science by integrating digital age literacy. A preliminary research needs to be done in developing this learning model.

In understanding the solution of this problem, there are four theoretical review. First theoretical review is learning model. Pathak (2012) states that a model of teaching is a plan or pattern that can be used to shape curricula, to design instructional materials and to guide instruction in the classroom and other settings. Viswanath (2006) defines that a model of teaching consist of guidliness for designing educational activities and environments. It specifies ways to teaching and learning that are intended to achieve certain kinds of goal.

Second theoretical review is contextual learning. Hasruddin (2015) explains that contextual learning is an active learning design which provides a way to introduce the learning content with the variation of active learning to help students connect with their learning world. Davtyan (2014) states that contextual learning is a learning system that ties brain actions to crating patters that have meaning. It is called contextual approach because it helps teachers connect content that students learn academically with real world situations that usually students experience. This inspires students to make connections between knowledge and their lives.

Third theoretical review is integrated science. In learning process, when teachers integrate the subdisciplines within a subject area, they are using an intradisciplinary approach (Mubita, 2016). Intradisciplinary approach is integration within subject area. Integrated science integrates the perspectives of subdisciplines such as biology, chemistry, physics, and earth/space science (Drake, 2004).

Last theoretical review is digital age literacy. Turimen (2012) explains that the digital age literacy skills consist of basic literacy, scientific literacy, economic literacy, technological literacy, visual literacy, information literacy and multicultural literacy. This literasi is very important for students in digital era.

Preliminary research to develop adaptive contextual learning model of integrated science by integrating digital age literacy needs to be done. Results of this preliminary research can be used as basis for designing learning model. The objective of research is to describe supporting factors, integrated science learning, characteristics of students, and literacy of students. 


\section{Research Method}

This research can be classified into descriptive research method. Descriptive research is a research method that tries to describe and to interpret the object according the actual condition. This research has two main objectives are describe systematically facts and characteristics of the object that investigated accurately.

There are four instruments to collect data. First instrument is observation sheet to get data of integrated science learning in schools. Second instrument is student questionnaire to find data about characteristics of students in science learning. Third instrument is literacy test sheet to obtain data of digital age literacy of students.

Data analysis technique in this research is descriptive statistic analysis. Descriptive statistics is statistics that serve to describe object which investiged through the sample data. In this descriptive statistic without doing analysis and making conclusion that apply to the general conclusion. There are several data presentations in descriptive statistics such as: regular tables, frequency distributions, graphs, and explanation of data group through mode, median, mean, and standard deviation.

\section{Research Result and Discussion}

First research result is description of opportunity of applying integrated science learning. The instrument which used to obtain data is questionnaire sheet of six science teachers at three state junior high school with implementing the 2013 curriculum. The components of questionnaire sheet consist of six aspects namely: 1 ). curriculum, 2). teacher, 3). student, 4). facility and infrastructure, and 5). environment.

The mean value of the supporting factors of applying integrated science learning varies from 66.25 to 84.17. There are two average values of supporting factors that are already in the very good category namely curriculum and facility and infrastructure. Meanwhile, three other supporting factors are in the good category namely teacher, student, and environment. Average value of supporting factors is 76.83. The average value of supporting factors can be classified into good category.

The second result is description of science learning implementation in three junior high schools that has implemented the 2013 curriculum. Instrument to collect data was observation sheet of science learning. Integration of contextual strategy elements consists of five indicators are: 1). connecting, 2). experiencing, 3). applying, 4). collaborating, and 5). transfering. On the other hand, integration of science learning materials consists of six indicators namely: 1 ). holistic materials of science, 2). meaningful concepts, 3). direct experience, 4). student activities in learning, 5). integration between concept and subject matter, and 6). theme and sub themes in learning. Average value of contextual learning and integrated science learning materials shown in Figure 1 and Figure 2 


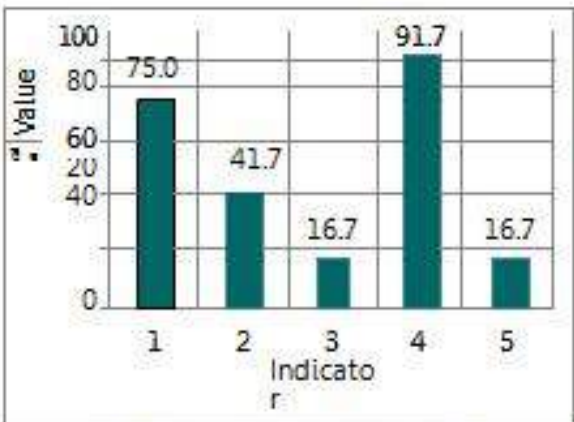

Fig 1. Integration of Contextual in Science Learning

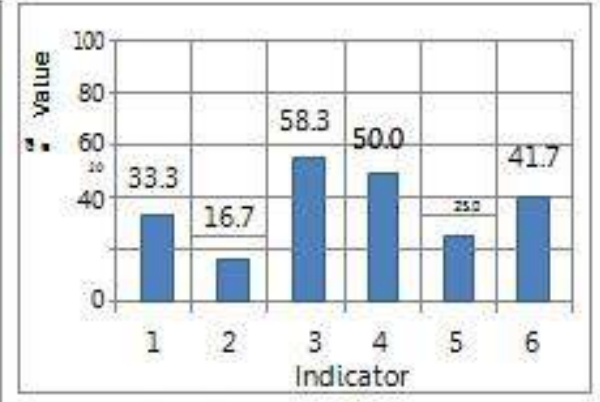

Fig 2, Integration of Science Material in Learning

The integration of contextual strategies elements that are already in very good category is to work together in group. The average value of connecting the learning materials with the real world is in good category. The average value of experiencing the physics process through experimental activities is in low category. On the other hand the average value of applying learning materials and transferring knowledge to new situation respectively in very low category. The average value of the fifth elements of contextual learning strategy is 48.3 which entered into low category. These results indicate that integration of contextual learning strategy is still low.

In integration of science learning materials, the value of the formation of direct experience of students in learning is in the enough category with average value is 58.3. There are two indicators of integration of science learning materials that are in the low category that is the emphasis of student activities in learning and the theme and sub theme in learning. Meanwhile, the three other indicators of integration are in the very low category which is the discussion of the holistic learning materials, the meaningfulness of the interconnecting between related concepts, and the integration between the concepts and the subject matter. The average value of the integration of the six indicators is 37.5. This average value indicates that the integration of science materials in learning is low.

Third result is the description of student characteristics. The instrument which used to collect data is questionnaire sheet. This questionnaire consists of five components of students characteristics including: 1). background, 2). interest, 3). attitude, 4). motivation to learn, and 5). learning style.

Average value of student characteristics component varies 63.1 to 67.2. Average value of student characteristics is 65.88 . This value can be classified into good category. Component value of interest, attitude, motivation to learn and learning style is entered into good category. It means students have good interest, attitude, learning motivation and learning style in science learning. On the other hand the average value of the background component is in enough category.

Last result is description of digital age literacy of students. Literacy test was conducted on 176 students of grade VIII at three junior high schools in Padang. Components of literacy test including writing, describing information, scientific concepts, scientific processes, scientific contexts, and visual interpretation of literacy 
skill. The minimum value, mean value and maximum value of each school are shown in Figure 3

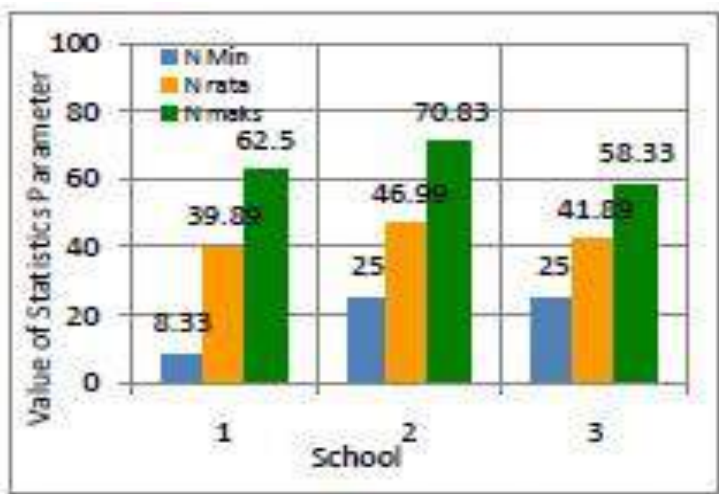

Fig 3. Value of Digital Age Literacy of Students

The minimum value of digital age literacy of students varies from 8.33 to 25.00. The maximum value of digital age literacy of students varies from 58.33 to 70.88. The average value of digital age literacy of students from each of junior high school respectively $39.89,46.99$ and 41.89 . The average value of digital age literacy of third state Junior High School is 42.92. This means that the average value of this digital age literacy is in the low category.

\section{Conclusion}

From data analysis, it can be stated four results of this preliminary research. First, average value of supporting factors of applying integrated science learning is 76.83. Second, integration average value of contextual learning strategy and science materials in learning respectively 48.3 and 37.5. Third, characteristics of students in the aspect of background, interest, attitudes, learning motivation is good with average value 65.9 while background of students is enough category. Finally, average value of digital age literacy of students is 42.92 and this value can be included into low category.

\section{References}

Davtyan, Ruzanna. (2014). Contextual Learning. ASEE Zone I Conference, April 3-5, University of Bridgeport, Bridgpeort, CT, USA.

Carroll, Crystal Jayne. (2013). The Effects of Parental Literacy Involvement and Child Reading Interest on the Development of Emergent Literacy Skills. Dissertation, The University of Wisconsin-Milwaukee

Drake, Susan M and Burns, Rabecca C. (2004). Meeting Through Inntegrated Curriculum. Association for Supervision and Curriculum Development

Drake, Susan M and Savage, Michael J. (2016). Negotiating Accountability and Integrated Curriculum from a Global Perspective. International Journal of Learning, Teaching and Educational Research Vol. 15, No. 6, pp. 127-144

Gurria, Angel. (2010). PISA 2009 Results: What Students Know and Can Do. Student Performance in Reading, Mathematics and Science. Programme for International Students Assessment, OECD. 
Gurria, Angel. (2014). PISA 2012 Results in Focus: What 15-year-olds know and what they can do with what they know. Programme for International Students Assessment, OECD.

Hasruddin, et all. (2015). Application of Contextual Learning to Improve Critical Thinking Ability of Students in Biology Teaching and Learning Strategies Class. International Journal of Learning, Teaching and Educational Research Vol. 11, No. 3, pp. 109-116.

Mubita, Simamuna Likando and Kalimaposo, Kalisto. (2016). Factors Affecting Teaching and Learning of Home Economics in the Integrated Primary Curriculum: A Study of Selected Primary Schools in Lusaka province of Zambia. International Journal of Multidisciplinary Research and Development. Volume 3, Issue 11, Page No. 09-16

Maryati, Purwanti Widhy Hastuti, dan Eko Widodo. (2012). Tingkat Pemahaman dan Kesulitan Pelaksanaan Pembelajaran IPA Terpadu SMP/MTS di Daerah Istimewa Yogyakarta. Universitas Negeri Yogyakarta.

Phatak, R.P and Chaudhary, Jagdeesh. (2012). Educational Technology. Dorling Kindesley, India.

Turiman, Punia, et all. (2012). Fostering the 21st Century Skills through Scientific Literacy and Science Process Skills. Elseiver, Procedia - Social and Behavioral Sciences, 59 ( 2012 ) 110 - 116

Vishwanath, V.N. (2006). Model of Teaching in Environmental Education. Discovery Publishing House. New Delhi, India.

Yuliati, L. (2013). Efektivitas Bahan Ajar Terpadu Terhadap Kemampuan Berpikir Tingkat Tinggi Siswa SMP. Jurnal Pendidikan Fisika Indonesia 9: 53-57, ISSN: 1693-1246. 